\title{
The effects of finish type on permeability and organoleptic properties of python (Python reticulatus) skin finished leather
}

\author{
Emiliana Kasmudjiastuti*, Rihastiwi Setiya Murti \\ Center for Leather, Rubber, and Plastics, Jl. Sokonandi No. 9 Yogyakarta 55166, Indonesia \\ *Corresponding author. Telp.: +62 274 512929, 563939; Fax: +62 274563655 \\ E-mail: emil bbkkp@yahoo.com
}

Received: 31 August $2016 \quad$ Revised: 4 November $2016 \quad$ Accepted: 9 March 2017

\begin{abstract}
In the leather industry, there are many different types of finish, i.e. two-tone, transparent, semi aniline and opaque/solid color. The composition formulation of each finish type is different so each will impact not only on the performance but also on the properties of the finished leather. The objective of this research was to investigate the effects of finish type (natural, aniline, semi-aniline, and two-tone) on permeability and organoleptic properties of python skin finished leather. This research focused on the finishing process with various finish types. The results showed that the effect of semi-aniline (I,II) finish type on water vapor permeability reduction is the highest when compared with natural (I, II); aniline (I,II) and two-tone finish types. Otherwise, the effect of semi-aniline (I,II) finish type on organoleptic properties is the lowest compared with natural (I, II); aniline (I,II) and two-tone finish types. The aniline I finish type has better organoleptic properties.
\end{abstract}

Keywords: finish type, natural, aniline, semi-aniline, two-tone, python skin.

\section{INTRODUCTION}

The python (Python reticulates) skin, known as Sanca skin, is included on Appendix II of CITES (Convention on International Trade in Endangered Species of Wild Fauna and Flora). It is one of the snakes that is not protected and can be traded (Menteri Perdagangan, 2013).

Generally, reptile skin finished leather only used protein/casein binder or nitrocellulose lacquer emulsion as the top coat, without pigment, so the leather grain will look like the original (Sumarni et al., 2013). In general, the coating composition includes pigments, binders, dyes, wax, plasticizer, filler, and penetrator (Niculescu et al., 2012; Gumel \& Dambatta, 2013) and the top coat uses nitrocellulose lacquer emulsion (Niculescu et al., 2015). Plating treatment will help flatten the formed film coating so that the layer of the film becomes compact, permanent and resistant to rubbing using either dry or wet cloth (Kasmudjiastuti, 2014). In the leather industry, there are many different types of finish i.e. two-tone, transparent, semi-aniline, and opaque/solid color. Two-tone finish is the second color either sprayed lightly or wiped over the original color or the lighter color wiped first before darker color is applied over it. Transparent finish is found on aniline and natural finish types. Aniline and natural finish types are the most natural look leather with unique surface characteristics. Aniline finish type is applied on dyed crust leather and natural finish type is applied on crust without dyestuffs. Both allow natural marking and grain of the leather to show through. The materials for coating usually use casein or protein binder. Casein binder is a binder that comes from milk, available as water-soluble colloid and one of natural components of milk. Casein binder is an easily degraded material of natural polymers, has good adhesive properties and resistant to high temperatures (Ma et al., 2012). Casein binder is used in small quantities because of its hardness, which could cause dry wrinkled folds and gives them more brightness and transparency. Nitrocellulose lacquer emulsion, when used for the top coat, can provide a transparent coating on the surface of the leather (Gumel \& Dambatta, 2013) as well as protein and casein binder. Protein binder gives a fine grain pattern, good breathability, and natural feel. Semi-aniline finish contains a small amount of pigment. Opaque color finish contains a 
big amount of pigment. It is not satisfying for finish on reptile skin. The finish must stick when it is applied, otherwise it will peel or crack. Good finish ensures good rub fastness and adhesive strength of paint cover. The top coat gives properties like appearance, handle, fastness to wet and dry rub resistance against hot plating and reduces the tackiness of binders used in the top coat (Wakaso, 2014).

The leather is an excellent three-dimensional matrix porous network, so it has the ability to blow (breathe). Porosity is an important parameter, which allows the leather to blow air (breathability) (Fathima et al., 2010). Water vapor permeability (WVP) is the amount of moisture that can penetrate the leather in the area and at a certain time that is expressed in the unit of $\mathrm{mg} / \mathrm{cm}^{2} . \mathrm{h}$ (BSN, 1998). WVP is its ability to allow moisture to pass through it. WVP is one of the most valuable physical properties of leather, which may greatly affect the breathability and comfort of leather goods (Tang et al., 2013). The properties of materials for leather goods is mainly associated with the softness and WVP (Smiechowski et al., 2014). Leather has better WVP compared to synthetic leather. Unfinished leather has better WVP than finished leather (Tang et al., 2013). Leather treatment at high temperatures $\left(100-150^{\circ} \mathrm{C}\right)$ will lower the WVP. Mechanism of WVP is only transporting water molecules through capillaries in leather driven by water pressure difference between two sides of the leather sample (Tang et al., 2013). The spread of water vapor velocity decreases after heat treatment, most likely due to a reduction in the number of macromolecular hydrophilic group of collagen and decreases the porosity of leather (Smiechowski et al., 2014). WVP is influenced by the retanning process and the fatliquoring, but very important for finishing process is including chemical structure of the finishing solution (Smiechowski et al., 2014; Tang et al., 2013). In the finishing process, some finishing agents are applied to the surface of the leather to add aesthetic value to the leather finish, while reducing air permeability (Sathish et al., 2015). Thick leather does not affect WVP, but thick layer affects WVP. The thicker the layer, the lower the WVP (Smiechowski et al., 2014). According to Gulbiniene et al. (2007), transfer of water vapor depends on the number of binders and pigments, and each affects WVP and layer thickness will reduce the permeability of the leather. The thinner the film, the better the breathability of the leather (Bekele, 2014). Leather is a unique material with the ability to breathe through porous network. Breathability and leather permeability and porosity are associated with the chemicals on the leather surface (Gil et al., 2013).

The aim of this study was to investigate the effect of finish type (natural, aniline, semi-aniline, and two-tone) on permeability and organoleptic properties of python (Python reticulates) finished leather. A research related to the type of finish has been undertaken by Kasmudjiastuti et al. (2015) on lizard (Varanus salvator) skin, with a discussion on mechanical tests, organoleptic, and observation of the photomicrograph. This study focused on the observation of permeability and organoleptic properties of python skin finished leather.

\section{MATERIALS AND METHODS Materials}

Experiments were conducted with 14 (fourteen) dried python skins obtained from Sumatera island in Indonesia, wetting agent, sodium sulfide, slaked lime, degreasing agent, bating agent, ammonium chloride, formic acid, sulfuric acid, sodium bicarbonate, mimosa powder (Brand Extract from Czechoslovakia), white syntan, fatliquors, dyestuffs, fungicide, liquid dyestuffs, pigments, protein binder, casein binder, urethane and acrylic resin binder, thinner and nitrocellulose lacquer.

\section{Methods \\ Apparatuses}

The apparatuses used were rotary drum: Otto Specht serial number 80304, easel, hand sprayer, hand staking tool, toggling machine, glazing machine, plating machine, thickness gauge, $\mathrm{pH}$ stick, tensile strength tester: Zwick Roell ZO20 type KAP-TC serial number 074170 made in Germany, crockmeter tester: AATCC, model M238 AA serial number 708B0086, adhesion of finish tester: STD 112 serial number 11446 , water vapor permeability apparatus: Wallace REF W2 serial number C 73097/2 made in England, and Scanning Electron Microscopy: SEC type SNE 3200 M.

\section{Tanning process}

The tanning, carried out in processing dried python skin, used mimosa powder. The formulation of tanning process shown in Table 1 (Kasmudjiastuti et al., 2015).

\section{Finishing process}


Table 1. The formulation of tanning process from dried raw python skin.

\begin{tabular}{|c|c|c|c|c|}
\hline Process & Product & $\%$ & $\mathrm{pH}$ & Duration (minutes) \\
\hline Soaking & $\begin{array}{l}\text { Water } \\
\text { Wetting agent } \\
\text { Soda ash } \\
\text { Cismolan UAL }\end{array}$ & $\begin{array}{l}800 \\
0.5 \\
0.3 \\
0.5\end{array}$ & $9-10$ & $\begin{array}{l}30 \\
30\end{array}$ \\
\hline $\begin{array}{l}\text { Washing } \\
\text { Liming }\end{array}$ & $\begin{array}{l}\text { Water } \\
\text { Water } \\
\text { Slaked lime } \\
\text { Sodium sulfide }\end{array}$ & $\begin{array}{c}300 \\
300 \\
5 \\
2\end{array}$ & $11-12$ & 10 \\
\hline $\begin{array}{l}\text { Washing } \\
\text { Scales removing }\end{array}$ & Water & 300 & & 10 \\
\hline $\begin{array}{l}\text { Washing } \\
\text { Fleshing } \\
\text { Weighing }\end{array}$ & Water & 300 & & 10 \\
\hline Deliming & $\begin{array}{l}\text { Water } \\
\text { Ammonium chloride }\end{array}$ & $\begin{array}{l}400 \\
1.5\end{array}$ & $7-8$ & \\
\hline $\begin{array}{l}\text { Washing } \\
\text { Bating }\end{array}$ & $\begin{array}{l}\text { Water } \\
\text { Water } \\
\text { Bating agent }\end{array}$ & $\begin{array}{c}300 \\
100 \\
0.5-1\end{array}$ & $7-8$ & $\begin{array}{l}10 \\
45\end{array}$ \\
\hline $\begin{array}{l}\text { Degreasing } \\
\text { Washing }\end{array}$ & $\begin{array}{l}\text { Wetting agent } \\
\text { Water }\end{array}$ & $\begin{array}{c}0.5-1 \\
300\end{array}$ & & $\begin{array}{l}60 \\
10\end{array}$ \\
\hline Pickling & $\begin{array}{l}\text { Water } \\
\text { Salt } \\
\text { Formic acid } \\
\text { Sulfuric acid }\end{array}$ & $\begin{array}{c}100 \\
10 \\
0.5 \\
0.5\end{array}$ & $2.5-3$ & \\
\hline $\begin{array}{l}\text { Pretanning } \\
\text { Tanning }\end{array}$ & $\begin{array}{l}\text { Pamol } \\
\text { Mimosa powder } \\
\text { Mimosa powder } \\
\text { Alum }\end{array}$ & $\begin{array}{l}2 \\
6 \\
6 \\
2\end{array}$ & & $\begin{array}{c}30 \\
45 \\
45+180 \\
60\end{array}$ \\
\hline Washing & Water & 300 & & 10 \\
\hline Neutralization & $\begin{array}{l}\text { Water } \\
\text { Sodium bicarbonate }\end{array}$ & $\begin{array}{c}150 \\
1\end{array}$ & & 60 \\
\hline $\begin{array}{l}\text { Washing } \\
\text { Retanning }\end{array}$ & $\begin{array}{l}\text { Water } \\
\text { Water } \\
\text { PWB } \\
\text { Retingan R7 } \\
\text { Novaltan PF }\end{array}$ & $\begin{array}{c}300 \\
100 \\
2 \\
3 \\
3\end{array}$ & & $\begin{array}{l}10 \\
45 \\
45 \\
45\end{array}$ \\
\hline Fatliquoring and dyeing & $\begin{array}{l}\text { Water } \\
\text { PWB } \\
\text { Leveling agent } \\
\text { Dyestuffs } \\
\text { Lipoderm liquor SPE } \\
\text { Lipoderm liquor SAF } \\
\text { Sandolix WWL } \\
\text { Formic acid } \\
\text { Fungicide }\end{array}$ & $\begin{array}{c}100 \\
3 \\
1 \\
2 \\
2 \\
2 \\
2 \\
1 \\
0.02\end{array}$ & & $\begin{array}{l}60 \\
10 \\
60 \\
60\end{array}$ \\
\hline $\begin{array}{l}\text { Washing } \\
\text { Pile } \\
\text { Staking } \\
\text { Toggling }\end{array}$ & Water & 300 & & 10 \\
\hline
\end{tabular}


There were seven variations performed in the finishing process with the formulation as shown in Table 2. They were natural I finish type (with casein binder), natural II finish type (with protein binder), aniline I finish type (with casein binder), aniline II finish type (with protein binder), semianiline I finish type (with liquid dyestuffs), semianiline II finish type (with liquid dyestuffs + pigment) and two-tone finish type. The formulation of finishing refers to Kasmudjiastuti et al. (2015). The treatments of finishing operation for natural I and aniline I finish types were brushing by pillowcase, glazing, and kiss plating; for natural II and aniline II finish types were spraying, glazing, and kiss plating; for semi-aniline were spraying and plating with pressure of 50-75 Bar, temperature $80^{\circ} \mathrm{C}$ for 2 seconds; and for two-tone were spraying with effect (not homogenous) and plating with pressure of $50 \mathrm{Bar}$, temperature $80^{\circ} \mathrm{C}$ for 1 second.

\section{Testing}

The test parameters of the results of the study focused on the effect of finish type on permeability and organoleptic properties of phyton leather, which included measurement of film thickness, water vapor permeability (WVP), rub fastness (dry, wet), and the adhesive strength of cover paint (dry, wet).

The thickness of film coating was measured by scanning electron microscopy technique using
300X magnifications.

WVP test method (BSN, 1998): Leather was cut into $5 \times 5 \mathrm{~cm}$ rectangular pieces of test piece and conditioned at $70 \% \mathrm{RH}$ with minimum temperature for 24 hours. Test piece was rubbed lightly with sand paper in all directions 10 times with maximum load of 200 grams and cut circular with a diameter of $36.0 \mathrm{~mm}$. Tes bottle was filled approximately $1 / 2$ of it with silica gel, put in dryer cabinet at $102-105^{\circ} \mathrm{C}$ for minimum 2 hours, and cooled in decicator.

Test piece was then placed with grain inside the mouth of bottle cap, the lid was tighten and then was weighed. The bottle and the test piece were mounted on WVP test equipment and spinned for minimum 7 hours. After that, the bottle and the test piece were weighed and the time from the first to second weighing was recorded.

WVP was calculated with equation (1):

$\operatorname{WVP}\left(\mathrm{mg} / \mathrm{cm}^{2} \mathrm{~h}\right)=7639 \cdot \mathrm{m} /\left(\mathrm{d}^{2} \cdot \mathrm{t}\right)$

Where $m$ was the difference of weight before and after test (milligram), $\mathrm{d}$ was the average diameter of bottle mouth (mm), $t$ was the time of the test (minute), and 7639 was conversion of unit

\section{Organoleptic test method}

Organoleptic test was conducted by 10 panelists, who are competent in the area of leather, to assess softness and appearance. The assessment criteria were as follows: very good with a score of

Table 2. The formulation of finishing for different finish type

\begin{tabular}{|c|c|c|c|c|c|c|c|}
\hline \multirow[t]{2}{*}{$\begin{array}{c}\text { Finishing } \\
\text { auxiliaries (gram) }\end{array}$} & \multicolumn{2}{|c|}{$\begin{array}{c}\text { Natural } \\
\text { (crust) }\end{array}$} & \multicolumn{2}{|c|}{$\begin{array}{c}\text { Aniline } \\
\text { (dyed crust) }\end{array}$} & \multicolumn{2}{|c|}{$\begin{array}{l}\text { Semi-aniline } \\
\text { (dyed crust) }\end{array}$} & \multirow[t]{2}{*}{$\begin{array}{l}\text { Two-tone } \\
\text { (dyed crust) }\end{array}$} \\
\hline & I & II & I & II & I & II & \\
\hline Water & 1000 & 750 & 1000 & 750 & 575 & 575 & 550 \\
\hline Casein binder & 30 & - & 30 & - & - & - & - \\
\hline Ammonia & 40 & - & 40 & - & - & - & - \\
\hline Cationic fatliquor & 10 & - & 10 & - & - & - & - \\
\hline Fixing agent: & & & & & & - & - \\
\hline Formaldehyde & 200 & - & 200 & - & - & - & - \\
\hline Water & 800 & - & 800 & - & - & - & - \\
\hline Protein binder & - & 250 & - & 250 & - & 75 & 75 \\
\hline Urethane resin & - & - & - & - & 50 & 50 & 50 \\
\hline Acrylic resin & - & - & - & - & 250 & 250 & 250 \\
\hline Liquid dyestuffs & - & - & - & - & 50 & 30 & 75 \\
\hline Pigment & - & - & - & - & - & 20 & - \\
\hline \multicolumn{8}{|l|}{ Top coat: } \\
\hline Nitrocellulose & - & - & - & - & 200 & 200 & 200 \\
\hline Thinner & - & - & - & - & 800 & 800 & 800 \\
\hline
\end{tabular}


91-100; good with a score of 81-90; adequate with a score of 71-80.

\section{RESULTS AND DISCUSSION Properties of Python Leather}

The properties of the leather may include film thickness of coating, WVP, rub fastness (dry, wet), the adhesive strength of cover paint (dry, wet) and organoleptic. The film thickness of coating is shown in Figure 1. The data of WVP, rub fastness (dry, wet), and adhesive strength of cover paint (dry, wet) are shown in Table 3 . The reductions of WVP of various types of finish are shown in Figure 2 and organoleptic properties are shown in Figure 3.

\section{Film Thickness}

The film forming in various finish types were not uniform. Therefore, it was important to measure the thickness of the film formed. The film thickness of each finish types was measured by scanning using electron microscopy technique at $300 \mathrm{X}$ magnifications. The film thickness of each finish type on python leather surface was measured and shown in Figure 1.

Figure 1 shows that the thickness of natural I (Figure 1(a)) coated surface was 53.85 microns; natural II (Figure 1(b)) was 58.15 microns; aniline I (Figure 1(c)) was 42.0 microns; aniline II (Figure 1(d)) was 44.7 microns; semi-aniline I (Figure 1(e)) was 48.8 microns; semi-aniline II (Figure 1(f)) was 104.0 microns; and two-tone finish (Figure $1(\mathrm{~g})$ ) was 38.9 microns. Unfinished (control) sample without coated surface (Figure 1(h)) had no thickness. Differences in film thickness were due to material compositions of finishing and coating, meaning that each type of finish was different.
The thinnest film was two-tone finish type with a film thickness of 38.9 microns. The thickest film was semi-aniline finish type II with a film thickness of 104.0 microns. According to Gulbiniene et al. (2007), transfer of water vapor depends on the surface of coating thickness (amount of binder and pigment) and film thickness will reduce the permeability of leather. WVP of the leather depended on the numbers of binders and pigments. The thickness of coating affects WVP. The thicker the film, the lower the WVP (Smiechowski et al., 2014). Otherwise the thinner of film, the higher the WVP (Bekele, 2014). The test results of WVP, rub fastness, and the adhesive strength of the cover paint are presented in Table 3 .

\section{WVP and Reduction of WVP on Various Finish Types}

WVP, in general, is measured by air volume pass through the leather of unit area in unit time. Its unit is $\mathrm{mg} / \mathrm{cm}^{2} . h$. The results of WVP are given in Table 3. According to Smiechowski et al. (2014), the value of WVP of unfinished leather is higher than WVP of finished leather. It is evident in Table 3 that the WVP of control (unfinished) was $15.95 \mathrm{mg} / \mathrm{cm}^{2}$, which was higher than the finished leather. The WVP value of two-tone finish type $\left(12.38 \mathrm{mg} / \mathrm{cm}^{2} . \mathrm{h}\right)$ was higher than the other finish types. The spread of water vapor velocity decreased after heat treatment, most likely due to a reduction in the number of macromolecular hydrophilic group of collagen and decreased the porosity of the leather (Smiechowski et al., 2014). The two-tone finish coating on the surface of the leather used a mix of base coat and liquid dyestuffs with thin spray to give a two-tone effect so that the coating film was thinner than the other.

Table 3. WVP, rub fastness, and the adhesive strength of the cover paints of various finish types on python leather.

\begin{tabular}{lccccc}
\hline \multirow{2}{*}{ Type of finish } & WVP & \multicolumn{2}{c}{ Rub fastness } & The adhesive strength of cover paint $(\mathrm{g} / \mathrm{cm})$ \\
\cline { 2 - 6 } & $\left(\mathrm{mg}^{2} \mathrm{~cm}^{2} . \mathrm{h}\right)$ & Dry & Wet & Dry & Wet \\
\hline Control (unfinished) & 15.95 & - & - & - & - \\
Natural I & 12.18 & $4 / 5$ & $4 / 5$ & 400.83 & 75.00 \\
Natural II & 11.45 & $4 / 5$ & $4 / 5$ & 258.33 & 150.00 \\
Aniline I & 11.63 & $4 / 5$ & $4 / 5$ & 350.00 & 75.00 \\
Aniline II & 11.56 & $4 / 5$ & $3 / 4$ & 541.67 & 75.00 \\
Semi-aniline I & 10.07 & $4 / 5$ & $4 / 5$ & 533.33 & 216.67 \\
Semi-aniline II & 9.60 & $4 / 5$ & $4 / 5$ & 245.83 & 129.17 \\
Two-tone & 12.38 & $4 / 5$ & $4 / 5$ & 275.00 & 175.00 \\
\hline
\end{tabular}




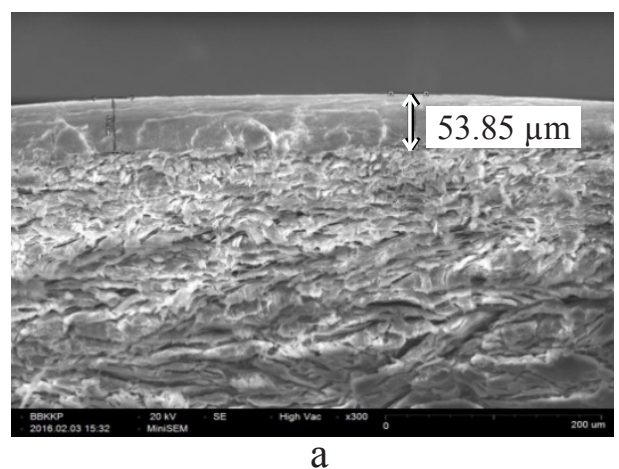

a

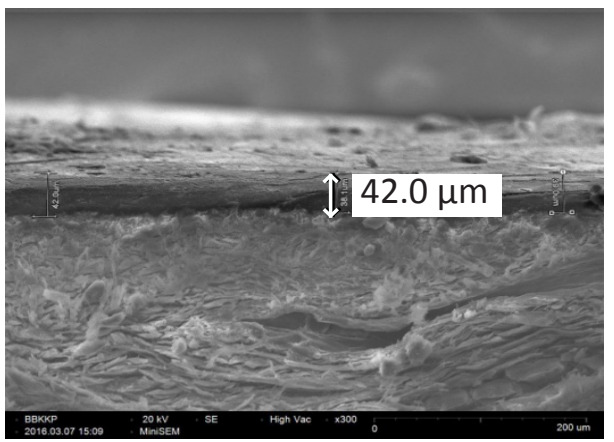

C

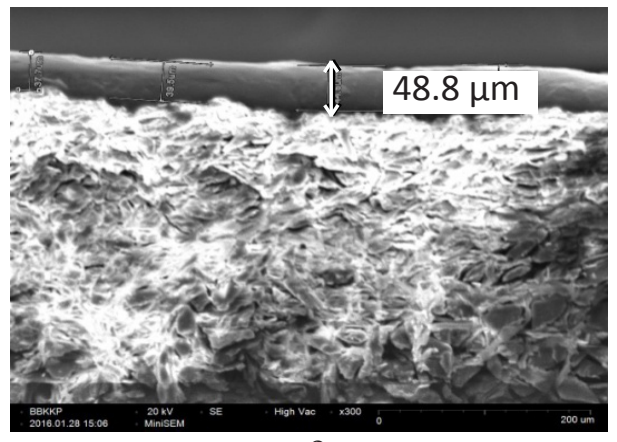

e

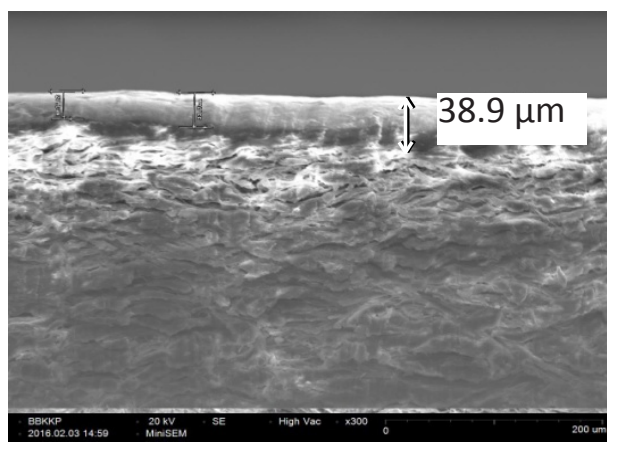

$\mathrm{g}$

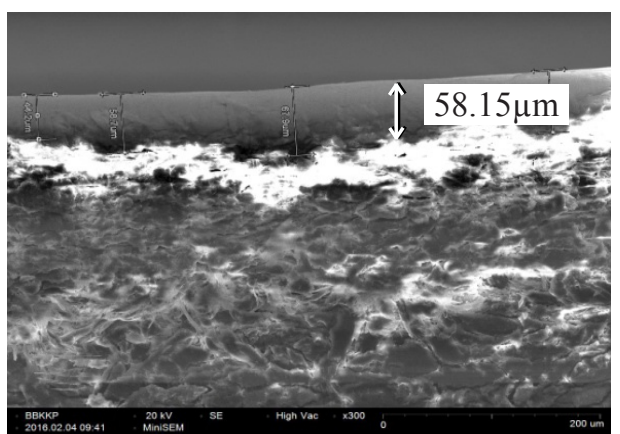

$\mathrm{b}$

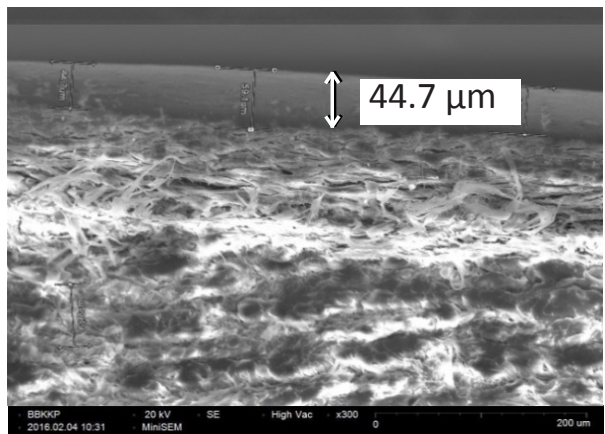

d

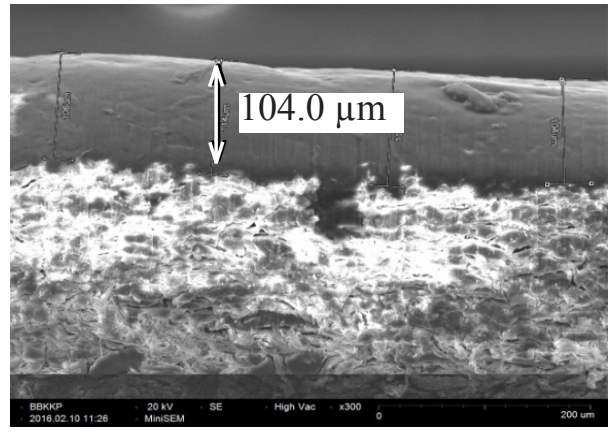

$\mathrm{f}$

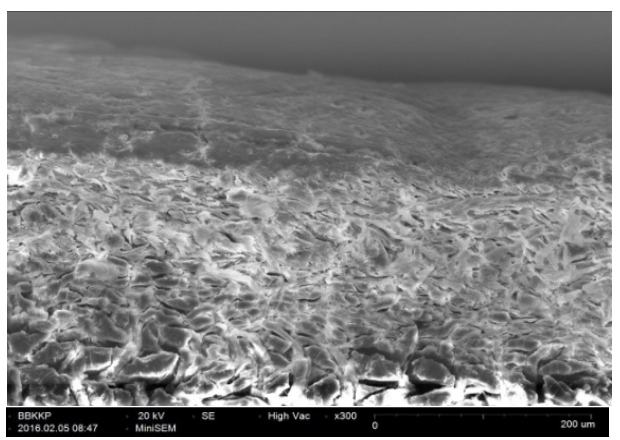

$\mathrm{h}$

Figure 1. Film thickness of (a) natural I; (b) natural II; (c) aniline I; (d) aniline II; (e) semi-aniline I; (f) semi aniline II; (g) two-tone; and (h) unfinished.

The WVP value of natural I finish type was higher than the natural II finish type (12.18 and $11.45 \mathrm{mg} /$ $\left.\mathrm{cm}^{2} . h\right)$. This was due to the differences in material composition and viscosity of the solution, so the leather surface porosity was affected. Natural
I finish type used casein binder, which dissolved in water $(30 \mathrm{~g} / 1000 \mathrm{~g})$, used more dilute solution compared with the natural II finish type, which used a protein binder material dissolved in water (250/750g). Similarly, the value of WVP aniline I 
finish type was higher than aniline II (11.63 and $11.56 \mathrm{mg} / \mathrm{cm}^{2} . \mathrm{h}$ ), due to the material composition. The viscosity was the same type as natural finish. The difference was aniline finish type which used dyed crust raw materials, while natural finish type used natural crust raw materials. The WVP value of semi-aniline II finish type was lower than the semi-aniline I ( 9.60 and $10.07 \mathrm{mg} / \mathrm{cm}^{2}$.h). It was also because the composition of the coating material of semi-aniline II was more solid than semianiline I as the composition of the coating material of semi-aniline II also contained pigment, thereby affecting the porosity of the surface of the leather and caused reduction in WVP. The highest WVP was the two-tone finish $\left(12.38 \mathrm{mg} / \mathrm{cm}^{2} . \mathrm{h}\right)$, which had the thinnest film (38.9 microns). The WVP value is influenced by the retanning and fatliquoring process, but the most important process is finishing process, including chemical structure of the finish (Smiechowski et al., 2014). In the finishing process, some finishing agents were applied to the surface of the leather to add aesthetic value to the leather finish, but it will reduce WVP (Sathish et al., 2015). To see the effects of various types of finishing in reducing WVP, equation (2) was used to calculate it and the graphic images are shown in Figure 2.

$$
\mathrm{WVP}_{\mathrm{R}}=\frac{\mathrm{WVP}_{\mathrm{BC}}-\mathrm{WVP}_{\mathrm{AC}}}{\mathrm{WVP}} \times 100
$$

Where $\mathrm{WVP}_{\mathrm{R}}$ is $\mathrm{WVP}$ reduction in percentage, $\mathrm{WVP}_{\mathrm{BC}}$ is WVP before coating (crust leather), and $\mathrm{WVP}_{\mathrm{AC}}$ is WVP after coating (finish leather).

The percentage of WVP reduction of each finish type can be seen in Figure 2. The highest WVP reduction was in semi-aniline II finish type with $39.8 \%$ reduction. The lowest WVP reduction was in two-tone finish type with $22.38 \%$ reduction. The reduction of WVP was due to the chemical substance applied to the surface of the leather in the finishing process (Smiechowski et al., 2014; Tang et al., 2013). It does not only consist of polymer as binder but also a wide range of additional materials which can close the pores of the leather surface. Moreover, due to the effects of heat treatment (glazing or plating treatment), the number of hydrophilic groups of macromolecule collagen were reduced and decreased the porosity of the leather (Smiechowski et al., 2014). Chemical substance for coating consisted not only of polymer as binder but also of various auxiliaries. Each of them might have covered the surface porosity of leather, which reduced the WVP of leather. The reduction of WVP by semi aniline (I, II) finish type was higher compared with natural (I, II); aniline (I,II) and two-tone finish types.

\section{Rub Fastness}

The values of wet and rub fastness of the finished leather are given in Table 3. The results indicated that finish type did not affect the rub fastness. The results of all finish type showed good dry and wet rub fastness with score $4 / 5$, indicating that sufficient binder or lacquer emulsion was used and the bonding between the pigment and the binder was strong. This showed that the formula of the top coat was compatible with the system/treatment, so that when it dried it formed a strong glue film coating on the surface of the leather. Top coat determined the final appearance and the handle of leather surface and it had decisive influence on the fastness proportion of finish. Moreover, heat and pressure treatments (plating/glazing) helped flatten the formed film coating, so that a layer of film became compact and permanent and resistant to rubbing with a dry cloth or wet cloth (Kasmudjiastuti, 2014).

\section{Adhesive Strength of Cover Paint}

The values of the effects of the finish types on the adhesive strength of the cover paint of the finished leather are shown in Table 3. The results indicated that the value of adhesive strength of cover paint (dry) was in a range 245.83-541.67 $\mathrm{g} / \mathrm{cm}$ and $75.00-216.67 \mathrm{~g} / \mathrm{cm}$ (wet). The highest value of adhesive strength of cover paint (dry)

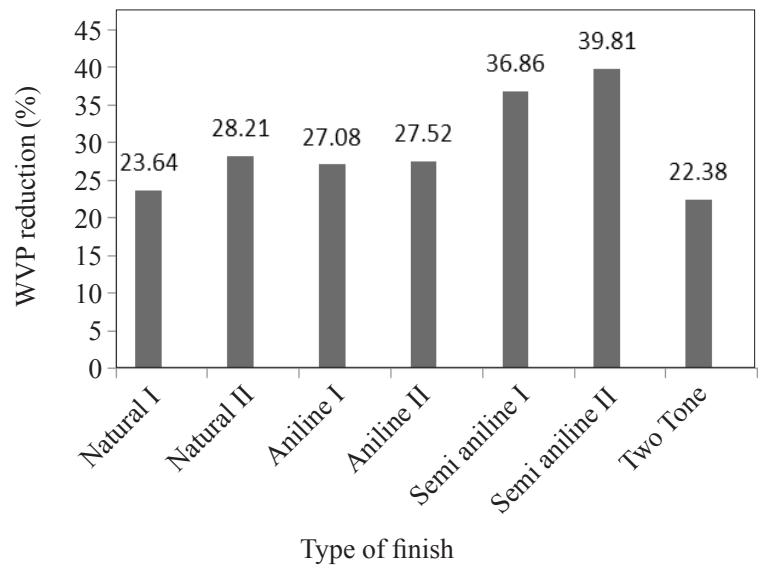

Figure 2. Percentage reduction of WVP on various finish types. 
was achieved by the aniline II finish type (541.67 $\mathrm{g} / \mathrm{cm}$ ) and $216.67 \mathrm{~g} / \mathrm{cm}$ for adhesive strength of cover paint (wet).

The finish coat must stick when applied on leather surface. Otherwise it will peel or crack. Adhesion is the degree of binding to the surface of the leather of a finishing layer, which used to improve the leather's physical characteristics. This showed that the composition of the material for the base coat was compatible with the composition of the material for the top coat, so it could become a powerful glue on the surface of the leather when coupled with plating treatments that enhanced adhesion to the surface of the leather due to their thermal energy.

\section{Organoleptic Properties of Leather (Perfor- mance of Leather)}

The finished leathers of all finish types had been evaluated for organoleptic properties by hand and visual evaluation. The average of rating for the leathers is given in Figure 3. Higher numbers indicated a better property.

Organoleptic test was intended to determine the extent of the softness and appearance of the python leather which used vegetable tanning with various types of finish. Organoleptic testing was judged by 10 panelists with average values as shown in Figure 3. The results showed the highest organoleptic test on the python leather was produced by aniline I finish type with a value of 92.6. It means that aniline I finish type had better softness and appearance than the other finish types. Semi aniline (I, II) finish type had lower organoleptic properties when compared with natural (I, II); aniline (I,II); and two-tone finish types.

The purpose was to produce finished ani-

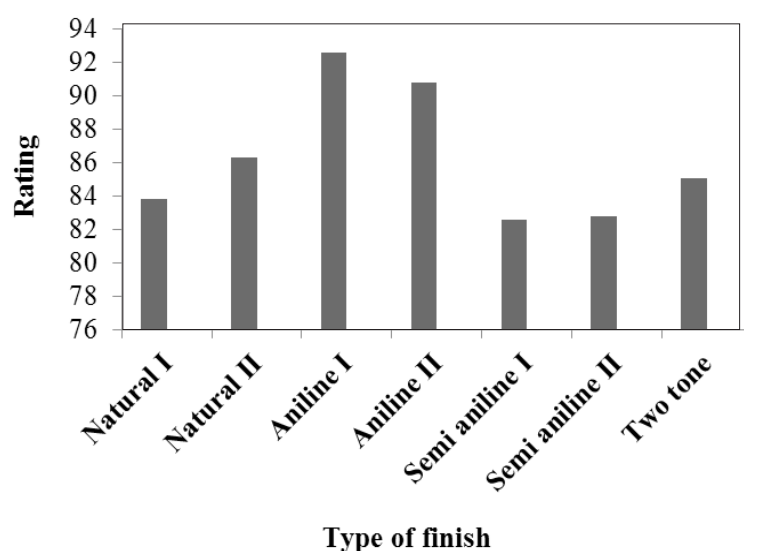

Figure 3. Organoleptic properties of the python leathers. line leather that had a natural appearance (natural look). It was evident that the selected panelists considered the best leather was the one that used aniline finish. For reptile leather finishing, the most important thing is the beauty of the grain and retaining of its original color and not being covered by the cap when using a paint pigment. To achieve this, the layer of film that is formed should be transparent. Reptile leather at the finish uses a protein or casein binder, finished leather looks transparent, and the grain look like the original (Sumarni et al., 2013).

\section{CONCLUSIONS}

Any type of finish affected the WVP and reduced WVP, film thickness, adhesive strength of cover paint, and organoleptic (performance) of leather finish, but did not affect the rub fastness properties. The aniline I finish type was the optimum treatment in this trial to produce python leather with the properties as follows: WVP of $11.63 \mathrm{mg} / \mathrm{cm}^{2} . \mathrm{h}$; rub fastness of $4 / 5$ (dry and wet); the adhesive strength of cover paint of $350 \mathrm{~g} / \mathrm{cm}$ (dry), $75 \mathrm{~g} / \mathrm{cm}$ (wet), WVP reduction of $27.08 \%$ and organoleptic value of 92.6 (very good).

\section{ACKNOWLEDGEMENTS}

The authors thank to the Center for Leather, Rubber and Plastics for the facilities and funding in this study.

\section{REFERENCES}

Bekele, M. (2014). Approach towards high performance water vapour permeability upper leather from goat skin (Thesis). Addis Ababa University, Ethiopia.

BSN (Badan Standardisasi Nasional). (1998). Standar Nasional Indonesia SNI 06-4587-1998 Cara uji tembus uap air pada kulit jadi. Jakarta, Indonesia: BSN.

Fathima, N. N., Kumar, M. P., Rao, J. R., \& Nair, B. U. (2010). A DSC investigation on the changes in pore structure of skin during leather processing. Thermochimica Acta, 501(1-2), 98-102, https://doi.org/10.1016/j.tca.2010.01.016

Gil, R. R., Ruiz, B., Lozano, M. S., \& Fuente, E. (2013). The role of crosslinking treatment on the pore structure and water transmission of biocollagenic materials. Journal of Applied Polymer Science, 130(3), 1812-1822, https:/doi.org/10.1002/app.39365

Gulbiniene, A., Jankauskaite, V., Saceviciene, V., \& Mickus, K. V. (2007). Investigation of water vapour resorption/desorption of textile laminates. 
Material Science (Medziagotyra), 13(3), 255-261.

Gumel, S. M., \& Dambatta, B. B. (2013). Application and evaluation of the performance of poly(vinyl alcohol) and its blend with nitrocelulose in leather top coating. International Journal of Chemical Engineering and Applications, 4(4), 249-253, https://doi.org/10.7763/IJCEA.2013.V4.305

Kasmudjiastuti, E. (2014). Optimasi proses finishing kulit ikan nila (Oreochromisniloticus) untuk bagian atas sepatu. Majalah Kulit, Karet dan Plastik, 30(2), 107-114, https://doi.org/10.20543/mkkp.v30i2.131

Kasmudjiastuti, E., Sutyasmi, S., \& Murti, R. S. (2015). Pengaruh berbagai jenis penyamakan dan tipe finish terhadap morfologi, sifat organoleptis dan mekanis kulit biawak (Varanus salvator). Majalah Kulit, Karet dan Plastik, 31(2), 115-126, https://doi.org/10.20543/mkkp.v31i2.505

Menteri Perdagangan. (2013). Keputusan Menteri Perdagangan Republik Indonesia Nomor 50/MDAG/Per/9/2013 tentang Ketentuan ekspor tumbuhan alam dan satwa liar yang tidak dilindungi undang-undang dan termasuk dalam daftar cites. Jakarta, Indonesia.

Niculescu, O., Leca, M., Coara, G., Macovescu, G., \& Chelaru, C. (2012). Characterization of coating aqueous disperse systems used in natural leather finishing. Revista de Chimie, 63(9), 900-905.

Niculescu, O., Moldovan, Z., Leca, M., Chelaru, C., Alexandrescu, L., \& Aboul-Enein, H. Y. (2015). Characteristics of natural leather finished with some ecofriendly mixtures of polymeric aqueous dispersions. Journal of Polymer Engineering, 35(5), 463-470, https://doi.org/10.1515/polyeng-2014-0286
Ma, J., Xu, Q., Zhou, J., \& Wang, Y. (2012). Preparation of casein based silica nano-composite leather finishing agent via double in-situ emulsion polymerization. In The 9th Asian International Conference on Leather Science and Technology. Taipei, Taiwan: TILA.

Sathish, M., Azhar, Z, M, J., Fathima, N. N., \& Rao, J. R. (2015). Effect of finishing auxiliaries on permeability of leathers. Journal of American Leather Chemists Association, 110, 372-378.

Śmiechowski, K., Żarlok, J., \& Kowalska, M. (2014). The relationship between water vapour permeability and softness for leathers produced in Poland. Journal of The Society of Leather Technologists \& Chemists, 98(6), 259-263.

Sumarni, S., Triatmojo, S., \& Nurliyani, N. (2013). Pengaruh penggunaan binder alami pada proses finishing kulit cakar ayam tersamak terhadap kekuatan sobek dan ketahanan gosok cat. Buletin Peternakan, 37(1), 41-48, https://doi. org/10.21059/buletinpeternak.v37i1.1958

Tang, K., Wang, F., Liu J., Jia, P., \& Liu, J. (2013). Water vapour permeability of leathers by grey system theory. Reviews on Advanced Materials Science, 33(4), 373-382.

Wakaso, M. (2014). Studies on effect of different pigment and binder combination on surface property of finished leather (Thesis). Addis Ababa University, Ethiopia. 
